\title{
Do Tourist Expenditures Matter for Growth in Botswana? A Vector Auto Regression Approach
}

\author{
Strike Mbulawa \\ Botho University, Botswana \\ smint50ooo@gmail.com \\ Samuel Chingoiro \\ Botho University, Botswana \\ chingoiro@yahoo.co.uk
}

The study examines the role of tourism as a potential driver of economic growth in a middle-income economy. Specifically, the study analyzes the short run relationship between economic growth and tourist expenditures using annual time series data from 1980 to 2015 . The study is motivated by the fact that tourism is being given priority in devising strategies for rural and national development. Botswana has enjoyed economic growth since independence at an annual average of $9 \%$, which is considered one of the fastest in the world. Though mining revenues have been given the credit for the development of the economy, it is also important to realize the contribution of other important sectors like tourism in the context of an emerging economy. Using the vector auto regression approach, the study supports unidirectional causality moving from tourist expenditures to growth. Findings show that growth responds immediately to shocks in tourist expenditures up to six periods. However, tourism expenditures are not a key driver of growth and their effect on growth face diminishing returns. Demand side policies should focus on reducing inflationary pressures, which improves demand for products by tourists and increases growth. Supply side policies should focus on providing adequate finances to tour operators and tax incentives. These can improve the level of innovation and infrastructure development that are important in extending the impact of tourist expenditure on growth beyond six periods. They will also improve the contribution by FDI inflows in improving tourist expenditures.

Keywords: Botswana, tourism, causality, economic growth

https://doi.org/10.26493/2335-4194.10.91-101

\section{Introduction}

The development of tourism and its contribution to growth and poverty reduction has gained popularity in recent years. Pioneering work (Lea, 1988; Sinclair, 1998) shows that tourism can promote economic growth through creating employment and income generation. The tourism sector is still emerging and it is highly labor intensive, which can contribute pos- itively to the socio-economic wellbeing. The rise in tourist revenues boosts foreign exchange income, increases employment potential and brings economic growth (Samimi, Sadeghi, \& Sadeghi, 2011). The proceeds from tourist activities also act as a form of export income which can be used subsequently for investment purposes in the goods market. The national economy benefits from taxes extracted from increased 
revenues. Tourism development brings growth in critical sectors like agriculture, manufacturing, retail and transportation. The growth in the tourism sector is expected to continue as countries develop and their incomes rise. This allows people to have extra income to spend on leisure, which requires countries to develop strong tourism sectors to take advantage of the growth patterns (McCatty \& Serju, 2006). On the global front (United Nations Conference on Trade and Development 2013), the market share of tourist attractions of emerging economies made a huge increase of between thirty and forty seven percent in 2010. Emerging economies are growing faster than developed economies as tourist destinations for people from developed economies. Tourist arrivals in Sub Saharan Africa had grown by $14 \%$ between 2009 and 2010. This was represented by an increase from 20.5 million to 21.5 million in the two years, and this further increased to 28 million tourist arrivals in 2015 (RETOSA, 2011). The United Nations World Tourism Organization (2004) also shows that tourism accounts for approximately $55 \%$ of service sector exports.

The direction of causality between tourism and growth remains unsettled. Previous studies acknowledge the potential for growth to drive tourism and, alternatively, the existence of a tourism led growth hypothesis (Makochekanwa, 2013; Holzner, 2010; Samimi et al., 2011). Results have been sensitive to the measure of measures for growth and tourism, and more so on the data set employed. This leaves policy makers in different countries having no proper direction to follow. Findings generated elsewhere are not tenable in the context of Botswana, where discussions are ongoing on how to diversify the economy. Lack of clarity on the direction of causality leaves room for further interrogation in the context of Botswana. Whilst acknowledging studies done in an African context (Padachi, Seetanah, \& Rojid, 2010; Nkurayija, 2011; Makochekanwa, 2013), this study extends the current knowledge by focusing on Botswana with a different data set and where no similar work has been done. The connection between tourism and growth is not automatic, but it depends on the national strategy, level of openness, institutional and regulatory framework. This makes results from country studies irrelevant in the context of other economies. This study seeks to determine the impact of tourism on growth in the short run, and vice versa. It seeks to find out whether or not economic growth leads to tourism, and vice versa? How do innovations and shocks in tourist expenditures influence growth in Botswana?

The study confirms that tourist expenditures' Granger-cause growth. The latter responds immediately to shocks in later, up to six periods. The study suggests the existence of diminishing returns to scale which suggests that effective policies are required to sustain the impact of tourism expenditure on growth. Tourism expenditure is not a key driver of growth in Botswana, but it is making marginal contributions despite the potential that it has. The level of Foreign Direct Investment (FDI) is important in increasing the level of tourist expenditures in the short term. Policies attracting FDI will subsequently improve indirectly as it works through attracting more tourists. In the case of Botswana, keeping low levels of inflation has a twofold effect: Improving the level of growth and attracting more tourist expenditures. These are all beneficial to the economy as confirmed by the results on causality. The rest of the study is organized as follows: Section two explains the developments in the tourism sector and connection with growth, section three reviews literature on the connection between economic growth and tourism development, section four explains the data methodology employed in this study, section five discusses the results and section six concludes and gives policy recommendations.

\section{Tourism Expenditure and Economic Growth in Botswana}

Botswana is a middle-income country, within the Southern Africa Development Community (SADC), with a population of about two million. Tourism is one avenue for addressing poverty without reliance on diamond revenues. The country has many wildlife species in Chobe and the Okavango Delta which generate tourist activities. The Botswana Tourism Master Plan (2000) shows that $17 \%$ of the country is designated as national parks and game reserves, and at least $20 \%$ are wildlife management areas. The Okavango is the largest inland wetland habitat in the world oc- 


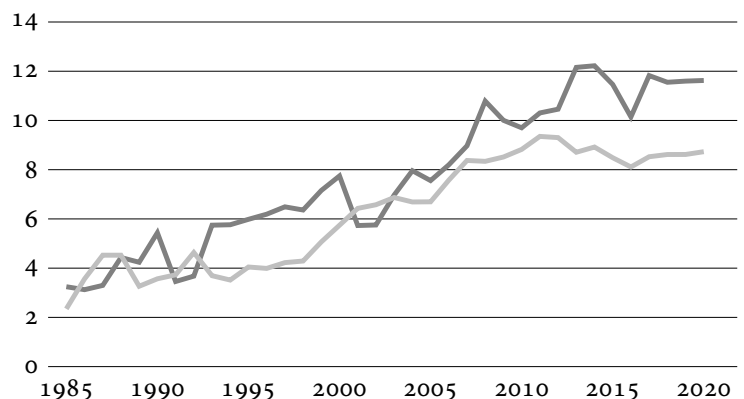

Figure 1 Total Turist Expenditures as Parcentage of GDP (dark - T TE, dark - T TESDC)

cupying $13,000 \mathrm{~km}^{2}$. The other national parks, like the Central Kalahari Game reserve and Kgalakgadi Transfrontier Park are not visited frequently by tourists. The country is recognized as a global tourism destination of choice, thus the need to exploit the tourism potential. Tourist expenditure comes from those in transit, business, leisure, and those visiting friends and relations (Ministry of Environment, Wildlife and Tourism, 2007; Joseph et al., 2010). The tourism sector witnessed an increase in holiday makers of 90\% between 1993 (106,800 visitors) and 1998 (203,172 visitors). The number of rooms grew by $33 \%$ during the same period. In 1998, employment within the sector was around $4.5 \%$ of the employed labor force. Thus, the contribution of tourism to economic growth has been in the form of visitors' expenditure, national output, foreign currency earnings, creation of employment and improved government revenues (Botswana Tourism Master Plan, 2000). The amount of tourist expenditures (T TE) as a percentage of Gross Domestic Product (GDP) has increased over the years (Figure 1). It has increased from below $3 \%$ in 1980 to $11 \%$ in 2015. This has performed better than the contribution of total tourist expenditure in SADC (TTESDC) which has increased from $2 \%$ to $9 \%$ over the same period.

Tourist expenditure patterns as a percentage of GDP have been improving over the years. Figure 2 shows that domestic tourism expenditure (DTS) has contributed more as compared to other types of expenditure like business tourism expenditure (В ТЕ) and leisure tourism expenditure (LTE). The highest contribution of $4.1 \%$ has been made by DTs, while

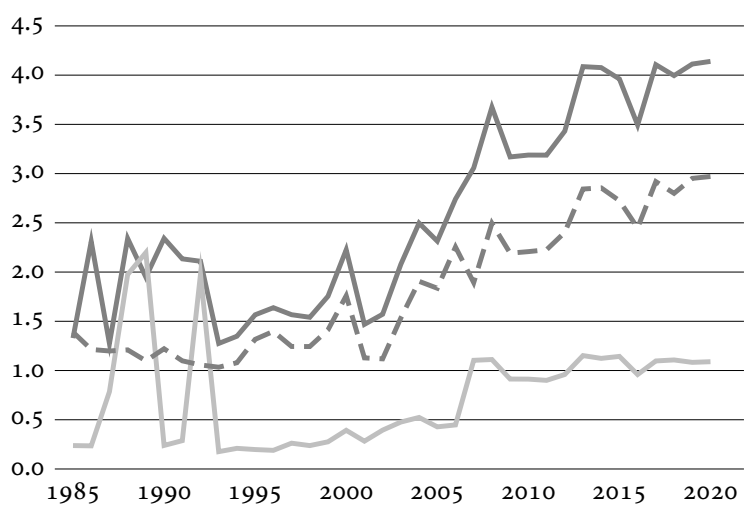

Figure 2 Tourist Expenditure Patterns as Percentage of GDP (dark - DTS, light - BTE, dashed - LTE)

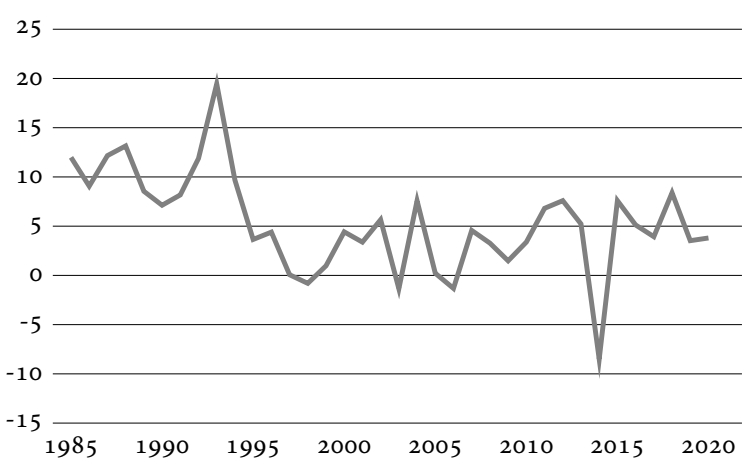

Figure 3 Botswana GDP Growth Rate (Percentage)

B T E contributed only $1 \%$. A huge potential on driving growth may be received from DTS and LTE, which can be sources for diversification. During the years of the global financial crisis (2008/2009) expenditure patterns fell, but they show improvements after 2010.

The growth rate in GDP (Figure 3) has remained positive since the year 1980, however it fell from being above $15 \%$ (1988) per annum to the current level of about $3.5 \%$ (2015). In 2009, it fell to negative $8.5 \%$, due mainly to the effects of the global financial crisis and a huge recovery was made within a year to positive $7.6 \%$. The growth rate in GDP is projected to remain below $5 \%$ beyond 2015 , and it has been unstable, which can be explained by changes in commodity prices.

\section{Review of Literature}

The connection between tourism and growth has been given attention by several researchers. Basically, there 
are three strands in literature: The first supports a tourism led growth hypothesis. Evidence from the World Travel and Tourism Council (see www.wttc.org) shows that tourism expenditure contributes to growth by generating income, employment, investment and exports. It can have both negative and positive effects, depending on the level of planning and development in a nation. Similarly, Nkurayija (2011) shows that tourism provides potential for diversification by attracting foreign direct investment, creating employment and boosting other government revenues. This is critical in the context of Botswana.

According to Makochekanwa (2013), tourism contributes to economic growth in varying proportions within different countries. The impact of tourism on growth was more significant in the Seychelles and Mauritius. The study found that a $1 \%$ increase in tourism led to a $0.16 \%$ increase in GDP within the SADC. Again, Narayan, Narayan, Prasad, and Prasad (2010) found that a $1 \%$ increase in tourism exports led to a $0.72 \%$ and a $0.24 \%$ increase in GDP in long and short runs respectively. These results are supported by Aleemi and Qureshi, 2015, who showed that tourism receipts have a significant and positive effect on GDP. They are contributing at least $0.24 \%$ of the GDP for Pakistan. Similarly, Wang and Xia (2013) support the existence of a dynamic long run relationship between tourism and economic growth. However, the study shows that, in the short term, GDP Granger causes tourism revenue and not vice versa. Tourism was found to benefit tourism dependent countries by causing average economic growth rates through high investment in capital in the form of infrastructure (Holzner, 2010).

On the other hand, Adamou and Clerides (2009a) argue that tourism specialization brings high growth rates at low levels of specialization. This is followed by diminishing returns, which results in tourism making a small contribution to growth. Hence, tourism led growth fails to be sustainable beyond a certain level of growth, which calls for other factors to take growth forward. Tourism (Eugenio-Martin, Morales, \& Scarpa, 2004) is adequate for growth in medium income countries and low-income countries, but it is not necessary for developed nations. Their study ar- gues that tourism only benefits countries where there is adequate infrastructure and human capital.

The second strand focuses on a fed back hypothesis which supports bidirectional causality between the two variables. Work has been done by several researchers and summarized as follows: Samimi et al. (2011) examined a causality and long run relationship between economic growth and tourism development using panel data and panel vector autoregression (panelvar) approach. The study shows bidirectional causality between the two variables in the short term and supports the positive impact of tourism development on growth. Similarly, Padachi et al. (2010) used a panel VAR approach and found bidirectional causality between the two variables using selected African countries.

The third strand argues that economic growth and tourism sector development have an insignificant relationship. McCatty and Serju (2006), show that the output multiplier for economy was small, such that, for every one dollar spent in the tourism sector, there would be one dollar increase in output which would drive employment by only 0.3 percent. Similarly, Homafar, Honari, Heidary, Heidary, and Emami (2011) examined the role of tourism on economic development, and their findings show that the impact of tourism on income production was minimal. Furthermore, Ekanayake and Long (2012) examined the link between the variables using data for developing countries. Results fail to provide evidence in support of the tourism led growth hypothesis. The positive elasticity of tourism revenue with respect to real income was statistically insignificant.

\section{Data and Methodology}

This study employs annual time series data for Botswana for the period 1980 to 2015 . The period was chosen based on the availability of data on key variables. The study employed a vector autoregression approach after establishing that the two main variables (economic growth and tourism expenditure) were not cointegrated. The study employed the method by Johansen to test for cointegration (1995). Impulse Response Functions (IRF) were used to test how each variable would respond to shocks made on another, 
and Forecast Error Variance Decompositions (FEVD) were used to test whether or not tourism expenditure was a key driver of economic growth. The variables employed, as explained hereunder, are as follows:

$$
\begin{aligned}
& \text { Economic growth }(\mathrm{GDPG}) \\
= & f(\mathrm{TO}, \mathrm{TTE}, \mathrm{FDI}, \mathrm{CPI}) .
\end{aligned}
$$

In this study, the vector autoregression (VAR) technique has been employed to explain the interdependences among variables. It is useful in examining the dynamic behavior of economic time series and for policy analysis. In a VA R system of equations, the behavior of a variable can be caused by its own changes in the past or by changes in other variables (Green, 2012). The causality between growth and tourism can be estimated using a bivariate auto-regression stationary series. In this study, there are three control variables, and, as such, a multivariate VAR is specified as follows:

$$
\begin{aligned}
\mathrm{GDPG}_{t}= & \beta_{\mathrm{o}}+\sum_{k=1}^{p} \beta_{k} \mathrm{TTE}_{t-k}+\sum_{k=1}^{p} \psi_{k} \mathrm{TO}_{t-k} \\
& +\sum_{k=1}^{p} v_{k} \mathrm{FDI}_{t-k}+\sum_{k=1}^{p} \phi_{k} \mathrm{CPI}_{t-k} \\
& +\sum_{k=1}^{p} \omega_{k} \mathrm{GDPG}_{t-k}+\varepsilon_{t} . \\
\mathrm{GDPG}_{t}= & \alpha_{\mathrm{o}}+\sum_{k=1}^{p} \alpha_{k} \mathrm{GDPG}_{t-k}+\sum_{k=1}^{p} \delta_{k} \mathrm{TO}_{t-k} \\
& +\sum_{k=1}^{p} \theta_{k} \mathrm{FDI}_{t-k}+\sum_{k=1}^{p} \varphi_{k} \mathrm{CPI}_{t-k} \\
& +\sum_{k=1}^{p} \eta_{k} \mathrm{TTE}_{t-k}+\varepsilon_{t} .
\end{aligned}
$$

where $\beta_{\mathrm{o}}$ is a constant, coefficients are represented by $\beta, \psi, v, \phi, \omega, \alpha, \delta, \theta, \varphi, \eta$ and $\varepsilon_{t}$ is an error term. Economic growth is represented by growth in GDP (GDPG). This is measured as an annual percentage growth rate of GDP at market prices based on constant local currency. GDP is the sum of gross value added by all resident producers in the economy, plus any product taxes and minus any subsidies not included in the value of the products. Trade Openness (то) was measured as total exports and imports divided by total
Table 1 Pairwise Correlation

\begin{tabular}{lcrrr}
\hline Variable & Loggdppc & T TE & TO & FDI \\
\hline Logdppc & 1 & & & \\
T T E & $0.7833^{*}$ & 1 & & \\
TO & 0.0553 & -0.0076 & 1 & \\
FD I & 0.1615 & 0.1669 & -0.334 & 1 \\
\hline Notes * Significant at 5\% level. & & &
\end{tabular}

GDP. Foreign Direct Investment (FDI) was measured as total foreign capital net inflows on investment. Inflation was measured by the Consumer Price Index (CPI). It reflects the annual percentage change in the cost to the average consumer of acquiring a basket of goods and services that may be fixed or changed at specified intervals, such as yearly. Data for all the preceding four variables were obtained from The World Bank (http://data.worldbank.org). Total tourist expenditure as a percentage of GDP (TTE) was used to capture the effect of tourism on economic growth. This was obtained from World Travel and Tourism Council (see www.wttc.org) and (see www.gov.bw).

The estimations proceeded as follows. We first tested for the presence of multicollinearity, using pairwise correlation, in the variables to avoid having spurious results. Stationarity tests were done using augmented Dickey Fuller (1979), the optimal lag length was tested using the Akaike Information Criterion (AIC) and causality tests were done using the method by Granger (1969).

\section{Discussion of Findings}

The results using pairwise correlation (Table 1) show that there was no problem of multicollinearity in the data. A positive correlation is suggested between economic growth and all three variables. This suggests that as the variables increase economic growth is expected to rise.

The summary statistics (Table 2) were used to explain the behavior of variables during the period. There was a total of 36 observations with mean values ranging between 3.17 and 102.69, being for FDI and то respectively. The average growth rate was $5.40 \%$ per annum during the period. Trade openness showed the highest volatility, which shows that the flow of 
Table 2 Summary Statistics

\begin{tabular}{lrrrr}
\hline Item & Loggdppc & T TE & TO & FD I \\
\hline Mean & 3.6274 & 8.8925 & 97.2128 & 3.1386 \\
Min & 3.3079 & 5.7315 & 85.8304 & 0.0377 \\
Max & 3.8753 & 12.2221 & 123.7871 & 13.4551 \\
SD & 0.1862 & 2.3569 & 10.1030 & 3.2318 \\
Kurtosis & 1.4280 & 1.4418 & 3.1628 & 5.2149 \\
Skewness & 0.0401 & -0.0248 & 0.9532 & 1.6240 \\
\hline Notes $N=29$. & & & \\
Table 3 Results for Unit Root & & &
\end{tabular}

\begin{tabular}{lrrrr}
\hline Variables & \multicolumn{2}{c}{ Levels } & \multicolumn{2}{c}{ First difference } \\
\cline { 2 - 3 } \cline { 5 - 5 } & $(1)$ & $(2)$ & $(1)$ & $(2)$ \\
\hline TTE & -1.093 & 0.7076 & -6.1798 & 0.0000 \\
GDPG & -3.843 & 0.0058 & & \\
TO & -1.921 & 0.3189 & -5.0278 & 0.0002 \\
FDI & -3.955 & 0.0044 & & \\
CPI & -2.434 & 0.1402 & -8.542 & 0.0000 \\
\hline
\end{tabular}

Notes Column headings are as follows: (1) test statistic, (2) probability.

trade between Botswana and her trading partners was not stable during the period. The least variable was economic growth, which remained around 5.09 on average. FDI, CPI and GDPG were distributed normally, while the other variables were not distributed normally since their value of kurtosis was below 3 . Evidence shows that all variables were skewed positively.

Table 3 shows that TTE, TO and CPI became stationary after first differencing. The probabilities given by Mackinnon were below $1 \%$. The other two variables (GDPG and FDI) were stationary at level. Variables were used in estimations at their level of stationarity.

Table 4 shows that the variables are not cointegrated. The $p$-values were higher than $5 \%$. This means that economic growth and tourist expenditure are related in the short term. This result suggests that the method by Granger (1969) should be employed in the analysis.

\section{Findings on Causality}

The results (Table 5), show that there is unidirectional causality moving from tourist expenditures to eco-
Table 4 Test for Cointegration: Johansen Method

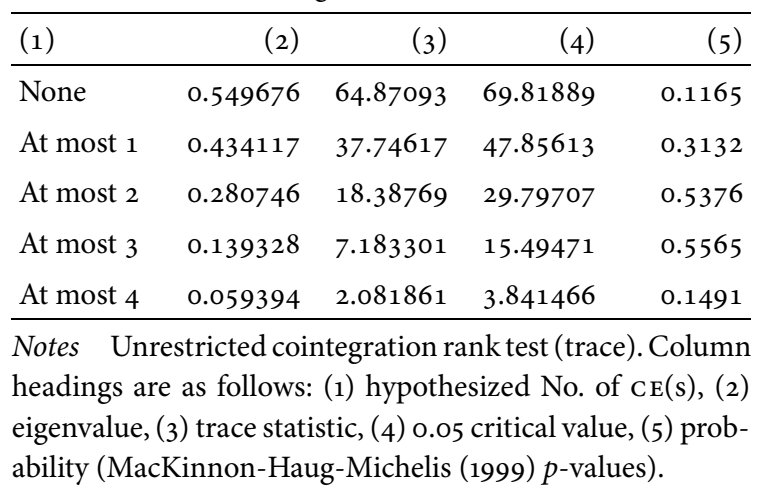

Table 5 Granger Causality Wald Tests

\begin{tabular}{|c|c|c|c|c|}
\hline Equation & Excluded & $\chi^{2}$ & $\mathrm{DF}$ & Prob. $<\chi^{2}$ \\
\hline D_loggdppc & D.TTE & 17.444 & 4 & 0.002 \\
\hline D_loggdppc & D.TO & 3.387 & 4 & 0.495 \\
\hline D_loggdppc & D.FDI & 15.570 & 4 & 0.004 \\
\hline D_loggdppc & All & 30.315 & 12 & 0.003 \\
\hline D_T TE & D. loggdppc & 21.230 & 4 & 0.000 \\
\hline D_T TE & D.TO & 8.004 & 4 & 0.091 \\
\hline D_TTE & D.FDI & 6.883 & 4 & 0.142 \\
\hline D_TTE & All & 51.837 & 12 & 0.000 \\
\hline D_TO & D.loggdppc & 25.411 & 4 & 0.000 \\
\hline D_TO & D.TTE & 40.076 & 4 & 0.000 \\
\hline D_TO & D.FDI & 25.667 & 4 & 0.000 \\
\hline D_TO & All & 70.479 & 4 & 0.000 \\
\hline D_FDI & D.loggdppc & 11.482 & 4 & 0.022 \\
\hline D_F D I & D.TTE & 6.606 & 4 & 0.158 \\
\hline D_FDI & D.TO & 2.189 & 4 & 0.701 \\
\hline D_FDI & All & 22.772 & 4 & 0.030 \\
\hline
\end{tabular}

nomic growth and not the other way round. This shows that the level of economic growth is sensitive to the level of expenditure by tourists. Specifically, the study shows that tourism expenditure has a positive impact on economic growth in the short term. The level of tourist expenditures can be useful in predicting the level of economic growth. Results in this study are consistent with previous studies (Nkurayija 2011; Makochekanwa, 2013; Adamou \& Clerides, 2009b; Aleemi \& Qureshi, 2015) which show that growth is 

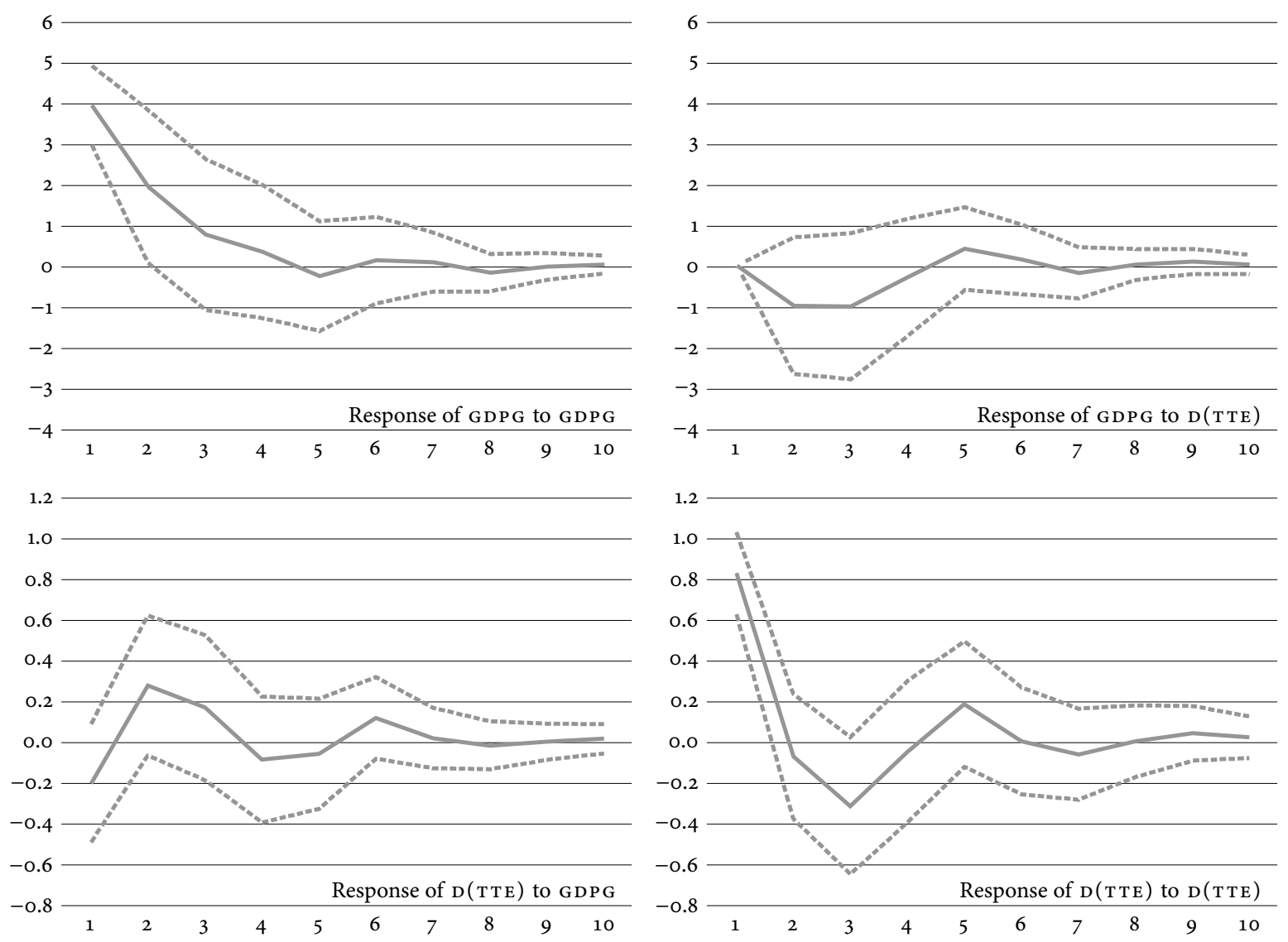

Figure 4 Impulse Response Function (Response to Cholesky One SD Innovations \pm 2 SE)

driven by expenditure on tourism. The increase in the level of growth is less than the proportional to the increase in tourist expenditures. The small contribution to growth is as a result of diminishing returns that are experienced in the short term. Findings show that the increase in growth from tourist expenditures may not be sustainable beyond certain levels. This finding is explained further by results from the Impulse Response Functions (IRF) discussed below.

The other key observation from the study is that growth can be explained by inflation. The study shows that causality between inflation and growth is unidirectional. It moves from the former to the latter. The study also shows that inflation can be helpful in predicting the levels of tourist expenditures in the short run. Causality moves from the latter to the former, which shows that the level of tourist expenditures is explained by inflation. The expectation is that low levels of inflation would attract more expenditure by tourists since services would be cheaper. This would eventually result in higher growth rates in the short term. These results have policy implications for monetary authorities.

The other important finding is that Foreign Direct Investment is useful in explaining the level of tourist expenditures. The former may provide opportunities for improving infrastructure which is critical for development of the tourism sector. In the event that F D I is used for improving infrastructure, it will be possible have high growth.

This is consistent with evidence from previous studies (Holzer, 2010; Malaj \& Kapiki, 2016). These studies show that investment in infrastructure is one way of extending the influence of tourist expenditures 

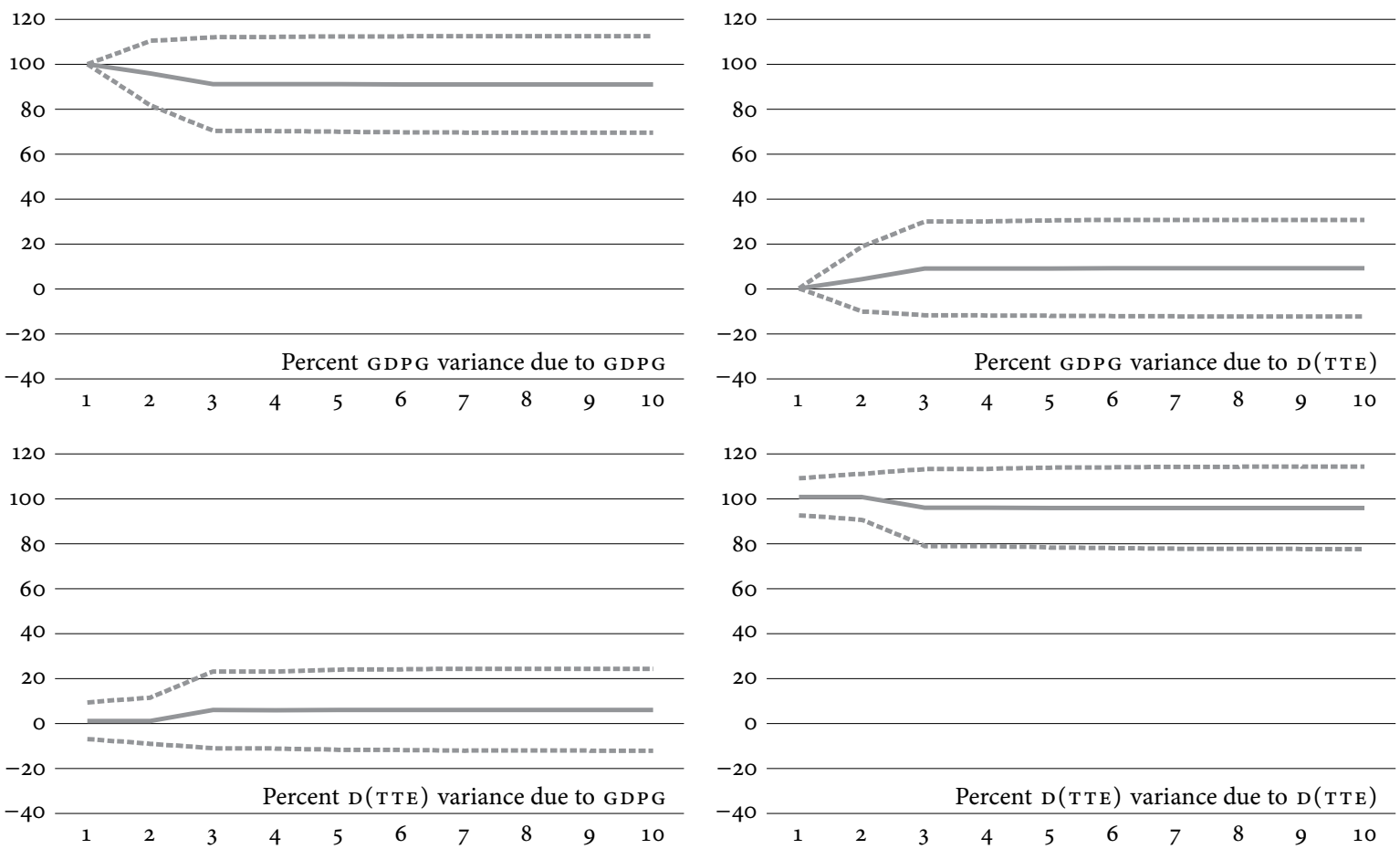

Figure 5 Forecast Error Variance Decomposition (Variance Decomposition $\pm 2 \mathrm{SE}$ )

on growth. It also increases the flow of tourists into a country as they enjoy better facilities. The level of openness has not been found to influence levels of growth and tourist expenditures during the review period.

\section{Impulse Response Function \& Variance Error Factor Decomposition}

The study also tested how changes in T TE would affect growth and vice versa. The findings in Figure 4 show that tourist expenditures respond significantly to shocks from growth and changes to its own levels. Shocks from the growth are expected to have immediate impact on T TE until the seventh period. Again, TTE is expected to respond immediately and significantly to its own changes until the 8 th period. The study shows that T T E would not respond to shocks in growth and its own levels after the 8th period. This may mean that other factors may be important in sustaining the growth in т т E. On the other hand, shocks to T TE would have an effect on growth starting from the same period. The impact of $\mathrm{T} \mathrm{TE}$ on growth would last until the 6 th period. This may be the time at which diminishing returns set in, as suggested by Adamou and Clarides (2009b). Again, shocks to growth are important in explaining the levels of growth in the future. The impact of changes of growth rate on growth is immediate, but it would subside after the 6th period.

The study used FEVD tests to establish the main drivers of growth and tourist expenditures. Findings (Figure 5) show that tourist expenditures are not the main driver of economic growth. The study shows that increased expenditures by tourists explain around 10\% of changes in growth. The changes in growth are explained mainly by its own changes, which accounts for over $80 \%$ of variations. The study also shows that economic growth does not explain many of the variations in T TE. In other words, the former is not a key driver of the latter. Evidence shows that changes in T TE are driven mainly by its own changes. Again, T TE is explaining over $80 \%$ of its own changes. Findings in this study have key policy implications. 


\section{Conclusion and Policy Recommendations}

The study sought to determine the impact of tourism development on economic growth and vice versa, to examine the response of economic growth to shocks in tourism expenditure and vice versa, and to test whether or not tourist expenditures are a key driver of economic growth. The study employed a vector auto regression approach to explain the dynamic relationship between economic growth and tourist expenditures. The key findings of this study support the tourism led growth hypothesis. This is not consistent with results by Rajapakse (2016a; 2016b), which show that GDP Granger causes tourism development. Tourism expenditures are important in explaining the short run growth. Tourism expenditures have a significant and positive impact on economic growth. In other words, tourism expenditure Granger causes short term growth. This is consistent with previous findings (Mazghouni \& Goaied, 2015; Gupta, 2015), which show that tourism is a key sector in developing economies, as it improves inclusive growth. The contribution of tourist expenditures to growth suffers from diminishing returns. This is shown by the IRF result, which provides evidence that tourist expenditures affect growth positively for up to six periods. The level of growth in previous periods was found to be important in explaining future levels of growth. This is also supported by IRF results, which show that growth responds quickly to its own shocks for up to six periods. The study showed that the main driver of growth was its own expenditure. This evidence is given by FEVD results, which show that previous levels of growth explain at least eighty percent of changes in future growth. Consistent with Rajapakse (2016a; 2016b), the level of tourist expenditures (T TE) is explained by FDI, which is important for putting in place suitable infrastructure. Lack of adequate infrastructure (Abdin, 2016) has been seen as a major hindrance to influx of tourists and, hence, low tourist expenditures. Causality moves from FDI to T TE. The former is important, particularly in sustaining the contribution of T TE to growth. Surprisingly, T TE was not found to be the key driver of growth. This result could have been obtained because of the limited number of control variables used in the model.
T TE is driven mainly by its own levels in the previous periods, and they respond to shocks in growth immediately. The study provides several policy implications: The government should focus on containing any inflationary pressures in the economy as this improves short growth and levels of $\mathrm{T} \mathrm{T} \mathrm{E}$. Inflation affects growth directly by improving output, and indirectly by improving expenditures by tourists as they enjoy lower prices for services. Policy makers should focus on attracting more FDI, as this sustains the contribution of tourist expenditures on growth. FDI inflows extend the effect of tourist expenditures on growth beyond the suggested six periods. Economic growth can be underpinned by revenues received from the tourism sector. The upgrading and maintenance, by using FDI flows, of tourist facilities, attracts more visitors, who will then spend more as they come for leisure and business trips. The country needs to take advantage of the more tourist attractions available by giving more incentives for people to stay longer at tourist facilities and spend more while in the country. Expenditures can be improved by focusing on the supply side. This means better quality products and services in line with tourists' taste should be made available. Incentives should be given to support innovation by tourist operators, and competition should be encouraged, as this improves quality and competitive pricing. Tax concessions can be given to new tour operators to promote entry into and stabilization in the industry. Availability of finance by local financial institutions can be channeled to the tourism sector to increase the capacity to develop more infrastructures, which brings growth to the economy. Infrastructure can be in the form of more tourist facilities, health care and roads. Continuous improvement of immigration laws will promote entry by visitors who are coming on holiday and/or business. According to Gupta (2015), it will also attract more FDI into the sector, which is vital for growth. Generally, the study supports the possibility of diversifying the economy using non-traditional sources of growth, tourism development. More studies may need to focus on exploring the potential of tourism development on growth and diversification. This may be done by considering the contribution of different flows from tourism, which can be business, 
leisure, domestic and foreign. It is still plausible to look at how tourism can contribute to social development. Studies can look at how tourism can improve welfare and reduce levels of economic ills like unemployment.

\section{References}

Abdin, J. (2016, 3 October). Policies required to develop tourism sector. The Independent. Retrieved from http:// www.theindependentbd.com/printversion/details/ 62384

Adamou, A., \& Clerides, S. (2009a). Tourism development and growth: International evidence and lessons for Cyprus. Cyprus Economic Policy Review, 3(2), 3-22.

Adamou, A., \& Clerides, S. (2009b). Prospects and limits of tourism led growth: The international evidence (Working Paper No. 41_09). Rimini, Italy: The Rimini Center for Economic Analysis.

Aleemi, A. R., \& Qureshi, M. A. (2015). Tourism receipts and economic growth: Empirical evidence from Pakistan. International Journal of Research, 2(2), 1401-1412.

Botswana Tourism Master Plan. (2000). Botswana tourism development programme (Project No. 7 АСР В Т 4/No. 6 ACP B T 44). Retrieved from: http://www.ub.bw/ip/ documents/

Dickey, D. A., \& Fuller, W. A. (1979). Distribution of the estimators for autoregressive time series with a unit root. Journal of the American Statistical Association, 74, 427431.

Ekanayake, E. M., \& Long, A. E. (2012). Tourism development and economic growth in developing countries. The International Journal of Business and Finance Research, 6(1), 51-63.

Eugenio-Martin, J. L., Morales, N. M., \& Scarpa, R. (2004, 19-20 September). Tourism and economic growth in Latin American countries: A panel data approach. Presented at the International Conference on Tourism and Sustainable Development - Macro and Micro Economic Issues, Sardinia, Italy.

Granger, C. W. J. (1969). Investigating causal relations by econometric models and cross-spectral methods. Econometrica, 37, 424-438.

Green, W. (2012). Econometric analysis (7th ed.). New York, NY: Pearson Education.

Gupta, R. (2015). Tourism, FDI and inclusive growth in India. Pacific Business Review International, 7(12), 108-114.

Holzner, M. (2010). Tourism and economic development: The beach disease? (Working Paper No. 66). Vienna, Austria: The Vienna Institute for International Economic Studies.
Homafar, F., Honari, H., Heidary, A., Heidary, T., \& and Emami, A. (2011). The role of sport tourism in employment, income and economic development. Journal of Hospitality Management and Tourism, 2(3), 34-37.

Johansen, S. (1995). Likelihood-based inference in cointegrated vector autoregressive models. Oxford, England: Oxford University Press.

Joseph, S., van Waarden, C., Mbaiwa, J., Brooks, C., Arntzen, J., \& Setlhogile, T. (2010). Tourism and heritage development. Gaborone, Botswana: Centre for Applied Research and Department of Environmental Affairs.

Lea, J. P. (1988) Tourism and Development in the third world. London, England: Routledge.

MacKinnon, J. G., Haug, A. A., \& Michelis, L. (1999). Numerical distribution functions of likelihood ratio tests for cointegration. Applied Econometrics, 14(5), 563-577.

Makochekanwa, A. (2013). An Analysis of Tourism Contribution to Economic Growth in SADC Countries. Botswana Journal of Economics, 11, 42-56.

Malaj, V., \& Kapiki, S. T. (2016). Determinants of tourism flows to Greece: A gravity model approach. Tourismos, 11(2), 202-224

Mazghouni, N., \& Goaied, M. (2015). The impact of tourism on economic growth: The Case of MENA region (19952013). Retrieved from https://ssrn.com/abstract $=2618598$

McCatty, M., \& Serju, P. (2006). Tourism, economic growth and employment (Working Paper). Kingston, Jamaica: Bank of Jamaica.

Ministry of Environment, Wildlife, and Tourism. (2007). Botswana: Strengthening Tourism Statistics and Formulation of an Experiemental TSA - 2005/2006. Retrieved from http://www.gov.bw/Global/citizens_pictures/ Tourism\%2oStatistics.pdf

Narayan, P. K., Narayan, S., Prasad, A., \& Prasad B. C. (2010). Tourism and economic growth: a panel data analysis for Pacific Island countries. Tourism Economics, 16(1), 169183.

Nkurayija, J. (2011). The impact of globalization on Africa's development: Rwandan tourism as key to mobilize revenue and investment. Butare, Rwanda: National University of Rwanda.

Padachi, K., Seetanah, B., \& Rojid, S. (2010). Tourism and economic growth: African evidence from Panel VAR framework. Retrieved from https://www.researchgate.net/

Rajapakse, R. P. C. R. (2016a). Tourist arrivals for Sri Lanka: An analysis of Granger causality. International Journal of Research in Economics and Social Sciences, 6(5), 183-193.

Rajapakse, R. P. C. R. (2016b). The relationship between foreign direct investment and tourism development: An 
analysis of Granger causality. Imperial Journal of Interdisciplinary Research, 2(6), 987-993.

RETOSA. (2011). Regional tourism growth and development strategy (Draft report). Retrieved from http://www.sadc .int/files/6813/5293/3534/

Samimi, A. J., Sadeghi, S., \& Sadeghi, S. (2011). Tourism and economic growth in developing countries: A P-VAR approach. Middle East Journal of Scientific Research, 10(1), 28-32.

Sinclair, M. T. (1998). Tourism and economic development: A survey. Journal of Development Studies, 34(5), 1-51.

United Nations Conference on Trade and Development. (2013). Sustainable tourism: Contribution to economic development growth and sustainable development. Retrieved from http://unctad.org/meetings/en/

SessionalDocuments/ciem5d2_en.pdf
United Nations World Tourism Organization. (2004). Tourism and poverty alleviation: Recommendations for action. Madrid, Spain: Author.

Wang, B., \& Xia, M. (2013). A study on the relationship between tourism industry and regional economic growth: A case study of Jiangsu Gaochun District. Modern Economy, 4(7), 482-488.

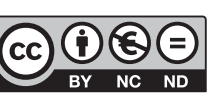

This paper is published under the terms of the Attribution- NonCommercial-NoDerivatives 4.0 International (CC BY-NC-ND 4.0) License. 